\title{
TRANSFORMATIONAL OR TRANSACTIONAL: LEADERSHIP STYLE PREFERENCES DURING THE COVID-19 OUTBREAK
}

\author{
Nelum Rathi ${ }^{1 *}$, Kamran Ahmed Soomro ${ }^{2}$ and Fraz Ur Rehman ${ }^{3}$
}

\begin{abstract}
The role of leadership is crucial to measure and enhance employees' performance and job satisfaction. Employee performance is directly proportional to the supervisor's behavior and their affiliations with the employees but the type of leadership style needs to be specifically evaluated aligning with the nature of employees. The purpose of applying leadership style is to extract realistic behavior of employees and their expected behavior concerning supervisors' behavior. Meanwhile, Covid-19 has left an immense psychological impact on employees which directly affects their attitudes, behavior and makes them more apprehensive towards tasks that cause more job efforts and build additional trust. The concept of conducting this research is based upon the sampling approach restricted to the private sector. The sample size for the study consisted of 243 responses collected through a convenient sampling technique. To analyze the data, regression was applied using the SEM-PLS method. The empirical findings underscored that transactional leadership style enhances employees' motivation and it has more influence on employee performance as compared to transformational leadership because transactional leaders motivate followers to perform at higher levels, to exert greater effort, and to show more work commitment.
\end{abstract}

Keywords: Transformational Leadership; Transactional Leadership; Trust; Job Satisfaction; Employee Behavior; Job Efforts; Covid-19; Pandemic.

\footnotetext{
${ }^{1}$ Shaheed Zulfiqar Ali Bhutto Institute of Science \& Technology, Karachi, Pakistan. Email: srathineelam@gmail.com

${ }^{2}$ Shaheed Zulfiqar Ali Bhutto Institute of Science \& Technology, Karachi, Pakistan.

${ }^{3}$ Shaheed Zulfiqar Ali Bhutto Institute of Science \& Technology, Karachi, Pakistan.

*Corresponding Author
} 


\section{INTRODUCTION}

A crisis is a testing situation of measuring leader's strength, meanwhile the difference between effective and ordinary leadership comes forward during the outbreak which highlights the handling methodology and productive conclusion during coping with crisis (Hasan \& Rjoub, 2017). As every sector occupies different layers, so different strategies of leadership are required to settle down particularly during the Covid-19. While every sector is striving to survive and is highly dependent on effective leadership, the telecom sector also demands serious attention during Covid-19 (Alves, et al., 2020). Telecom leaders also experience the unique catastrophe in the shape of Covid-19 and resultantly the telecom sector has to counter the crisis with a unique leadership strategy as well.

Leadership holds the basics of being able and organized to rouse others. Compelling administration and effective leadership depend on beliefs - both exceptional and attained - that are reliably reached to others in a method that links with them sufficient to move about as the leader wishes them to course. Effective leadership specifically in the Telecom Sector constitutes customer needs, customer financial constraint, conclusive responsibility regarding uninterrupted customer services, and ground complaint sorting strategies with polite courtesy is required in crisis management. Leadership is one of the fundamental tools for organizational management, as solid leadership can assist an organization with being progressively representative of trust, fulfillment, and responsibility, and it likewise accommodates people and assets to accomplish organizational objectives. (Pitelis \& Wagner, 2019; Samba, et al., 2018). Telecom is a growing sector, and Ufone is a leading telecom organization where the customer demands have been varying on daily basis and have intense competition among Teleorganizations. Thus to meet customer demands and uphold the completion, continuous contingent leadership style is adapted to counter the hopes and requirements, while leadership style is directly associated with the employee's outcome.

Meanwhile, the transformational style of Leadership consists of the attributes of symbolized impact idealization, rational incremental, and sole exchanging and has been recommended greatly as the effective methods for managing modification and demands the employees regarding keen interest and ability to get in the process (Broberg, E. K., et al., 2018). It is time and again observed that the Ufone leaders have widely observed, covered, formulated, and developed the strategies to consider the individual demographic requirements and inspire the users. Otherwise, the leaders feel reluctant to delegate responsibility. Similarly, the exclusive 
style of leadership will be adopted when the employees' ability to take part in the process remains low and the intention to delegate gets reduced.

Transactional leadership or utility-based administration is an integral part of Leadership. By an award and harshness system, transactional leaders can remain employees motivated for the temporary to achieve their goals. Leaders emerge during the crisis on the ground of crisis results, while visionary leader sorts the crisis while keeping the employees' interest in mind and rationality applies for the betterment of employees. Times of challenge and stress can also help improve previously poor employees' outcomes with the timely addition of exceptional leadership (Soydan \& Palinkas, 2014).

The main obstacles have been entertained as false information, contingent objectivity, vague and varied goals, and weak circumstances as a consequence of Covid-19, the head of the organization sees that representatives as one of the most significant resources that can lead the organization to progress. Employees tend to complain less about labor exceeding in the Covid19 and unpredicted Covid-19 situations because of an existing sense of firing. Per the Full Range of Leadership (FRL) model by Bass and Avolio (1994), the highest influential leadership styles are transformational and transactional leadership styles, if expected to motivate employees, impact the trust, job satisfaction, and employee's efficiency to improve their performance and outcome. The style of leadership as transformational or transactional identifies the employees' outcome along with job satisfaction and trust. Losing great workers implies losing satisfaction and trust through retaining them can assist organizations withholding information and undergo but leaders excel their employees to overtake few hopes (Fitch \& Van Brunt, 2016; Doucet, et al., 2015). This study will identify how leaders respond to the pandemic crisis to maintain employees' efficiency to produce the outcomes and can sustain the motivation among the employees to build trust and originate the will to perform additional work. Thus this study has two main questions, is transactional leaders' role important for employees' outcomes during times of crisis? And is transformational leaders' role important for employee outcomes?

\section{LITERATURE REVIEW}

The current Covid-19 crisis has indeed reminded everybody about the basic part of powerful administration and effective leadership that Leaders, executives, and administrations play by confronting unforeseen events that threaten the existence of organizations around the world. (Bundy, et al., 2017) Meanwhile, Telecom Sector is also impacted under the Covid-19 crisis 
and the leadership everywhere has adopted unprecedented steps to tackle the situation because of their influential impact, leaders achieve an expanded cogue of exchanging and evaluation during these harsh times. That's why individuals predict that leaders should give guidelines, comfort, honesty, and precise data. Like that unexpected highlight incorporated with robust needs for administration and effective leadership, grip delectations have been viewed to profit even non-conventional leaders as divisional help and extend the image of sustainability and allure (Hanif, et al., 2020).

\section{Roles of Leaders}

It is hard to envision an epidemic of Covid-19 as a chance, particularly one which we are encountering today. In any case, leaders who do will move their associations in certain manners. Managing a crisis as huge as the Covid-19, the pandemic will test the grit of great leaders all through an association and overall areas of the economy which include establishments of better learning (Rohrich et al., 2020). Drawing in interprofessional groups is particularly significant all through the emergency and beyond. Various experiences will reinforce the association's comprehension of what went right, what turned out badly, and how things ought to improve. Researchers have also noted that the targeted outcomes of leadership styles adopted by leaders influence subordinate performance and their outcomes (Madanchian et al., 2017; Haq et al., 2016).

Coping with crises hinges on the role of leadership in dealing with them, initiating with efforts to forecast them through working to restrict and limit their impacts, and closing with dealing and rewarding from their outcomes, and taking effective manners in dealing with them, where few leaders while their handlings with the crisis are considered to equal options and reaction policy, which may move towards the lowest to the obstacles of the organization from attaining its objectives, or reason luxurious losses that may drastically impact the organization's existence and lasting (Williams et al., 2017).

The secret of what effective leaders can and should do to start the best exhibition from their kin (Goleman, 2010). The presence of an organization is intently attached to the capacity or style of leaders. Consequently, the viability and effectiveness of organizations and leaders rely upon the powerful utilization of administration and leadership style (Berkovich \& Eyal, 2018), where the part of subordinates simultaneously and the working environment settings (under which the cycle of authority and leadership are occurring) are given equivalent significance (White et al., 2016). 


\section{Leadership Theory}

Leaders have been in presence since the days of yore. The idea of leadership was for a period seen as innate. It was accepted that leaders were destined to lead, this built up a hypothesis known as the Great Man's hypothesis or theory, which was dependent on the idea of chivalrous leaders. The theory of charismatic leadership suggested that leaders who have the skills and ability. Impacting vision to inspire their followers is simply considered to have unusual skills. Studies show that these leadership attributes push followers' behavior and beliefs toward achieving the organization's goals towards outcome and motivation (Zander, 2018).

Organizations require to born entire methodologies for leaders that will furnish them the source to originate the skills for creating trust, exchanging their thought, and developing convincing affiliation among employees and the organization. Leaders who pursue such arts are thought more productive by employees (Jamnik et al., 2013). Ufone's Leadership (EMT - Executive Management Team) is comprised of seasoned Telecom professionals who are well reputed for their ethical Leadership practices and are acknowledged for their mastery in their field outcome. The test for these leaders was, the way their style of leadership would be relevant in various settings and be powerful.

Leadership inspires individuals to get the desired and personified objectives and get the work done by others. Affective and inspiring leadership in Telecom Sector depends on belief-both traditional and gained - that is reliably transferred to others in a way that links with them sufficient to go about as the leader requires them to course. (Gutterman, 2020).

\section{Leadership style}

There are incalculable leadership styles along with management patterns and there isn't just a single viable approach to lead an association, however helpless and bad leadership will influence the assurance of the workers and the employee commitment especially in Telecom Sectors because the followers will not move for longer as the inconsistency prevails and hurt the expectations.

As the nature of leadership structure is complex and fluctuated, has multiple ways to evaluate the leadership (Mullins \& Debra, 2007). Effective leadership constitutes intuitive commitment, will rousting, conclusive obligation, and future predictability about crisis management. Chen \& Silverthrone (2005) have experienced numerous parameters about job satisfaction regarding employees. It was concluded that it hinges upon the coordination between employees and leaders. Such a relationship draws the relationship between work and relations as well. Leaders 
who build strong relationships among the different hierarchies of work produce more efficiency and effectiveness in output (Davis \& Rhodes, 2020). A crisis is a stage of testing the personal determination and the methodology to successfully manage the crisis and produce the desired conclusive result falls under the domain of effective leadership (Nyenswah et al., 2016). Park et al. (2018) described leadership is to create positive personal desires affiliation with the followers and ultimately develop the sense of attachment with the personal desire's goals because of followers' gain out of total proportion in a different context.

It was especially when difficult situations occurred that people felt they needed leadership (Karp \& Johannessen, 2010). Leadership is one of the fundamental requirements for organizational management, as solid leadership could assist an organization with being progressively representative of trust, accomplishment, and responsibility, and it likewise helps people and assets to embrace organizational objectives. (Pitelis \& Wagner, 2019; Samba et al, 2018).

\section{Transactional leadership}

Transitional leadership by making transparent roles and jobs methodology is defining by Robbins and Judge as leadership that assists or pulses supporters to get goals. It cannot vary from Burns's (1978) principle of transactional management that motivates its sticking by demanding its adherents' interests (Yukl \& Mahsud, 2010). Yukl said that transactional leadership needs boundaries for exchanging that can determine mission objectives vigorously. Meanwhile, the Telecom Sectors have dramatically exchanged the boundaries of requirements and cover all the expectations during Covid-19.

Transactional leadership or value-driven administration is a different style of leadership that hovers near about overlook, affiliations, and implementation. In Telecom Sectors, the leaders have built a strong affiliation and oversight between the leaders and employees, and it is the core part of Leadership (Niqab et al., 2019). Through the appreciation and evaluation system, transactional leaders can motivate followers in the short term to attain their goals. Transactional leaders may also penalize followers before those behaviors turn into important issues. Conversely, leaders may even be widely aggressive or rights-forgive and wait to interrupt till that teasing behavior metastasizes into bigger (Squires, 2018; Northouse, 2016)

Transactional leadership is also widely unproductive for communicating with workers/followers who, as to align with their work, routinely undergo variations and complications, depend upon experts, liberation, and getting, and demonstrate some extent of 
variations, liberty, and spontaneous. Gotsis and Grimani (2016) prescribes transactional leadership styles might also inaugurate further problems for leaders, notice "employees might also select to use their additional mind ability by suggesting or triggering their work if they are not pushed and awarded for the additional working in the organization." It can be said that transactional leadership is assisting when the leader is related more to the fulfillment of goals. Transactional leaders gradually use a carrot and stick ways to tackle completing those goals (Bass, 1997). . Transactional leaders have more tension about the accomplishments of the works and the implementation of employees. The reason being they use positive and negative tactics to attain the ideal outcomes.

\section{Transformational leadership}

Transformational leadership triggers an assumptive, progressives' appearance on the future, assert optimum hopes, concentrates employees' attention on an invisible, lasting approach, accommodate modification, and motivates new methodology at work (Steinmann et al., 2018). It has been observed that the Telecom Sector tremendously developed an idealistic and progressive approach for the consumer needs and requirements to cover the Covid-19 crisis. Transformational leaders furnish an expressive sight of goals that can assist in conquered narcissism and limited factiousness in firms. They enhance new and extended vibrant among employees. Conclusively, employees introduce optimum points of organizational commitment and enhance outcomes. Spinelli (2006) found that the connection between transformational. Because leaders have the moral obligations to motivate their followers to add value to the organizational success (Rohmann \& Rowold, 2009), an effective leadership style has been noted to move towards the better outcome (Turner \& Müller, 2005). In support of this, the association between the leadership styles and the attitude of employees to indulge extra efforts and job satisfaction as well as the impact on both subjective and objective performances.

Transformational leadership is greater familiar to lasting leadership, through which leaders inspire their workers to exceed specific wishes (Doucet et al., 2015; Hater \& Bass, 1988). Burns (1978) presented the approach of transformational leadership and according to him, the transformational leaders generally lead their personnel by offering them imagination and prescience. Meanwhile, in the telecom sector, the leaders have formulated the follower-benefits strategies to achieve maximum benefits and satisfy the needs in crisis as well Transformational leadership is a larger extent for an attractive leadership style and attempts to inspire employees by his approach and charisma. 
Transformational leadership style influences employees' willingness to put extra effort, have a feeling of satisfaction with supervisors, and perceive leaders to be effective (Bronkhorst et al., 2015; Avolio, Bass, \& Jung, 1999). The Transformational style of Leadership entails the factors of idealized impacts, influence, rational speediness, and individualized attention and has been prescribed largely as the high method for dealing with modification and demands the employees regarding keen interest and ability to get in the process. Moreover, Walumbwa et al. (2005) concluded that utilizing a transformational leadership style moves to enhance organizational commitment and job satisfaction.

\section{Leadership and Employees' Behavior}

To improve the exhibition of a worker, his/her reliance upon leadership and management, which is employable, has a distinct status. In a similar wonder, the focal function of the leader is to lead alongside his validity turns out to be generally noticeable (Bass et al., 2003). Studies led by Gibbs et al., (2013) researched compelling administration and leadership in advanced education settings to perceive explicit activities, practices, and indications of powerful leaders, for example, employees' job satisfaction, supervisor trust, and extra effort. Path-goal theory explains the factors which impact the employees' rewards and ultimate conclusion on the subordinates' behavior towards the outcome. Satisfaction and motivation that brings execution of change in the employees by the leader is a central area of path-goal leadership (Hodges \& Howieson, 2017). The path-goal theory highlights the employees' outcome which is based upon the employees' motivation and satisfaction with the work premise with the reward associated with additional efforts.

Trust is an important debate in organizations that have accumulated on performance appraisal, and if shattered is expected to have a severe counter effect. Trust is the sacred and affiliationoriented activity that needs to have existed in the process of following and guiding (McCarthy et al., 2010). Trust is fundamental for productive dispute, robust commitment, personal appraisal, and attaining cumulative objectives (Bello, 2012). Trust is a beneficial hope that the next will not behave with rewards (Gotsis \& Grimani, 2016). This is the hope of others in assertions, executions, or decisions made.

Employees' trust in leaders will expect employees following the rules and regulation as per organizational regulations, this will assist the executions of organizational modifications and enhance employee rewards in terms of performance, intention to leave, and social good behaviors (Van Zyl \& Lazeny, 2002 cited in Ponnu \& Tennakoon, 2009). The human capital 
theory argues that employees having more productive skills and efficiency always get more rewards and benefits. Telecom Sector requires the leaders to be proactive about the employees' motivation towards work because the telecom sector sometimes causes a hectic routine for the employees and ultimately needs variations in work premises to create additional work efficiency.

\section{RESEARCH HYPOTHESIS}

H1-There is an impact of transformational leaders on trust.

H2-There is an impact of transformational leaders on extra efforts.

H3- There is an impact of transformational leadership style on job satisfaction.

H4-There is an impact of transactional leadership style on trust.

H5-There is an impact of transactional leadership style on extra efforts.

H6-There is an impact of transactional leadership style on job satisfaction.

Figure 1. Conceptual Framework
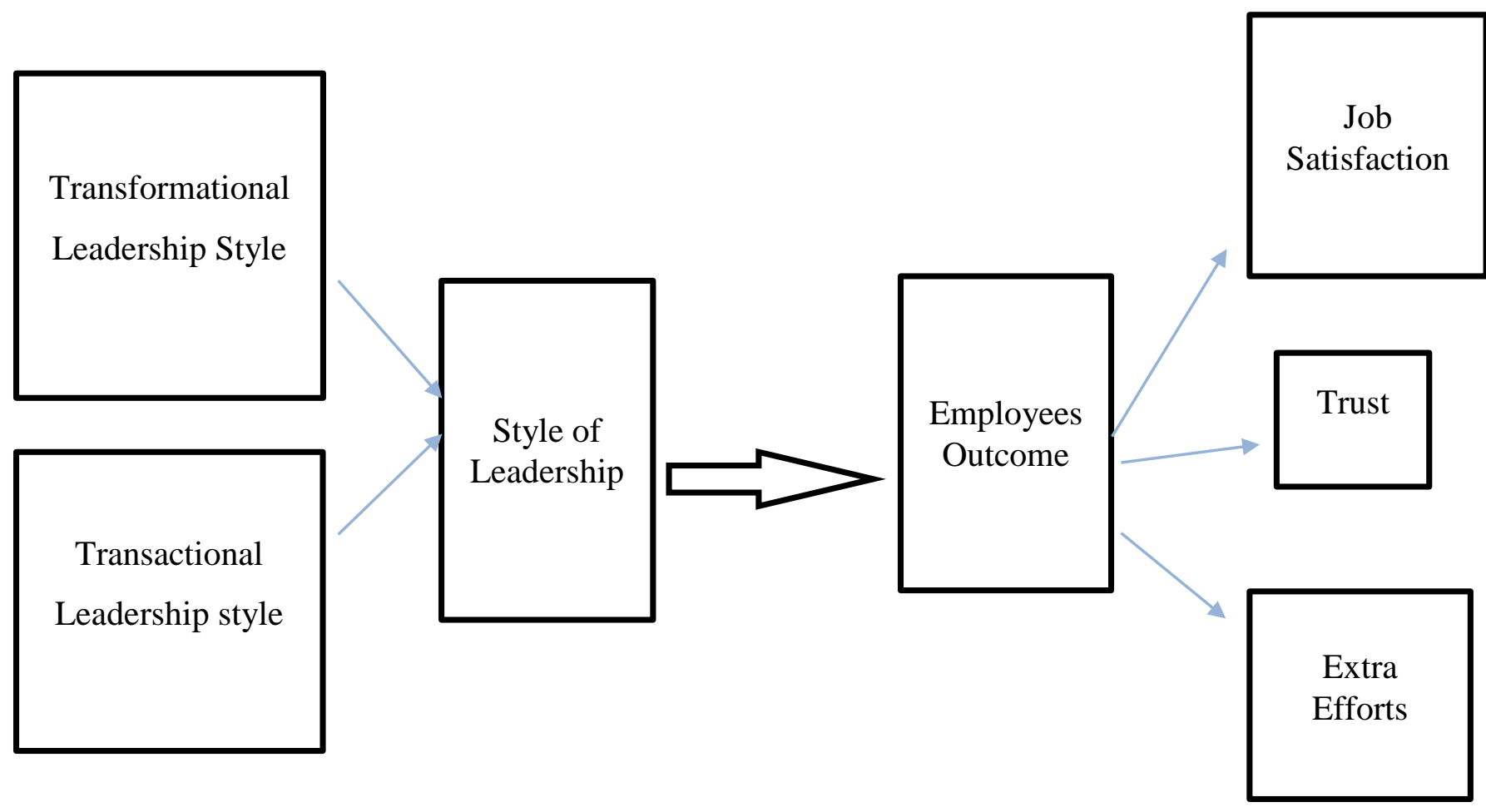


\section{RESEARCH METHODOLOGY}

Since this study is quantitative, the objectives of the research are to develop and test assumptions to support the conceptual framework of the study. Therefore, this study's deductive aapproach, best meets the research needs. The total population size is 600 but the Sample size consists of 243 participants (convenient sampling technique). This study will rely on a compressive survey method by online questionnaire distribution to the study population.

Table 1 shows the respondents' profile as given below that we have received the $59.29 \%$ and $40.74 \%$ from the males and females respectively in the context of gender distribution. Moreover, by the marital status, unmarried individuals have highly participated around $35.80 \%$ along with the $25.95 \%$ response by married. $25.92 \%$ participation was made by the age in between 32 and 39 but also responded by below 25 around 24.27\%. Meanwhile, in the context of educational qualification, the highest participation was counted by bachelors which are around $33.33 \%$ which is nearly below the master's participants that is $32.09 \%$ along with the second participation of about $22.22 \%$. Conclusively, the response in the context of job duration, $32.09 \%$ was executed by the participants having job duration in between 2 to 4 years and $23.45 \%$ by 8 to 10 years.

Table 1. Respondent's Profile

\begin{tabular}{|c|c|c|c|}
\hline Variable & Category & Frequency & Percentage \\
\hline \multirow[t]{2}{*}{ Gender } & Female & 99 & 40.74 \\
\hline & Male & 144 & 59.26 \\
\hline \multirow[t]{5}{*}{ Marital Status } & Single & 87 & 35.8 \\
\hline & Married & 63 & 25.9 \\
\hline & Divorced & 30 & 12.34 \\
\hline & Widowed & 30 & 12.34 \\
\hline & Separated & 33 & 13.58 \\
\hline \multirow[t]{6}{*}{ Age } & Below 25 & 51 & 24.27 \\
\hline & $25-29$ & 42 & 17.28 \\
\hline & $30-39$ & 63 & 25.92 \\
\hline & $40-49$ & 51 & 20.99 \\
\hline & $50-59$ & 24 & 9.7 \\
\hline & Above 60 & 12 & 4.93 \\
\hline \multirow{4}{*}{$\begin{array}{l}\text { Educational } \\
\text { Qualification }\end{array}$} & Secondary & 54 & 22.22 \\
\hline & Bachelors & 81 & 33.33 \\
\hline & Masters & 78 & 32.09 \\
\hline & Other & 30 & 12.34 \\
\hline \multirow[t]{2}{*}{ Length of Service } & One Year & 78 & 32.09 \\
\hline & $2-4$ years & 30 & 12.34 \\
\hline
\end{tabular}




\begin{tabular}{lcc}
$5-7$ years & 57 & 23.45 \\
\hline $8-10$ years & 18 & 7.407 \\
\hline $11-13$ years & 18 & 7.407 \\
\hline More than 15 years & 4 & 17.28
\end{tabular}

\section{Measures}

We used Li and Shi's (2008) scale with 6 items, with that to measure their current supervisor's behavior additionally, MQL 360 questionnaire is going to use to measure the transformational and transactional leadership style and satisfaction with the leader, and readiness to extra efforts. The questionnaire is based on Bass's (1985) theory of transformational and transactional leadership. The questionnaire is based on Bass's (1985) theory of transformational and transactional leadership. Further, the questionnaire for Trust and Job Satisfaction is adopted from (Hon \& Grunig, 1999), and readiness to exert extra effort on the job measured by scale MLQ 360 (5X short) is the latest version. Data is collected through e- questionnaire via mail and social groups like WhatsApp, Facebook due to Covid-19 restrictions. Smart PLS software was applied for statistical analysis, that software was used to measure and analyze the data collected from the respondents so that the relationship and impact between two variables can be found easily.

Figure 2. Reflective Measurement Model 1

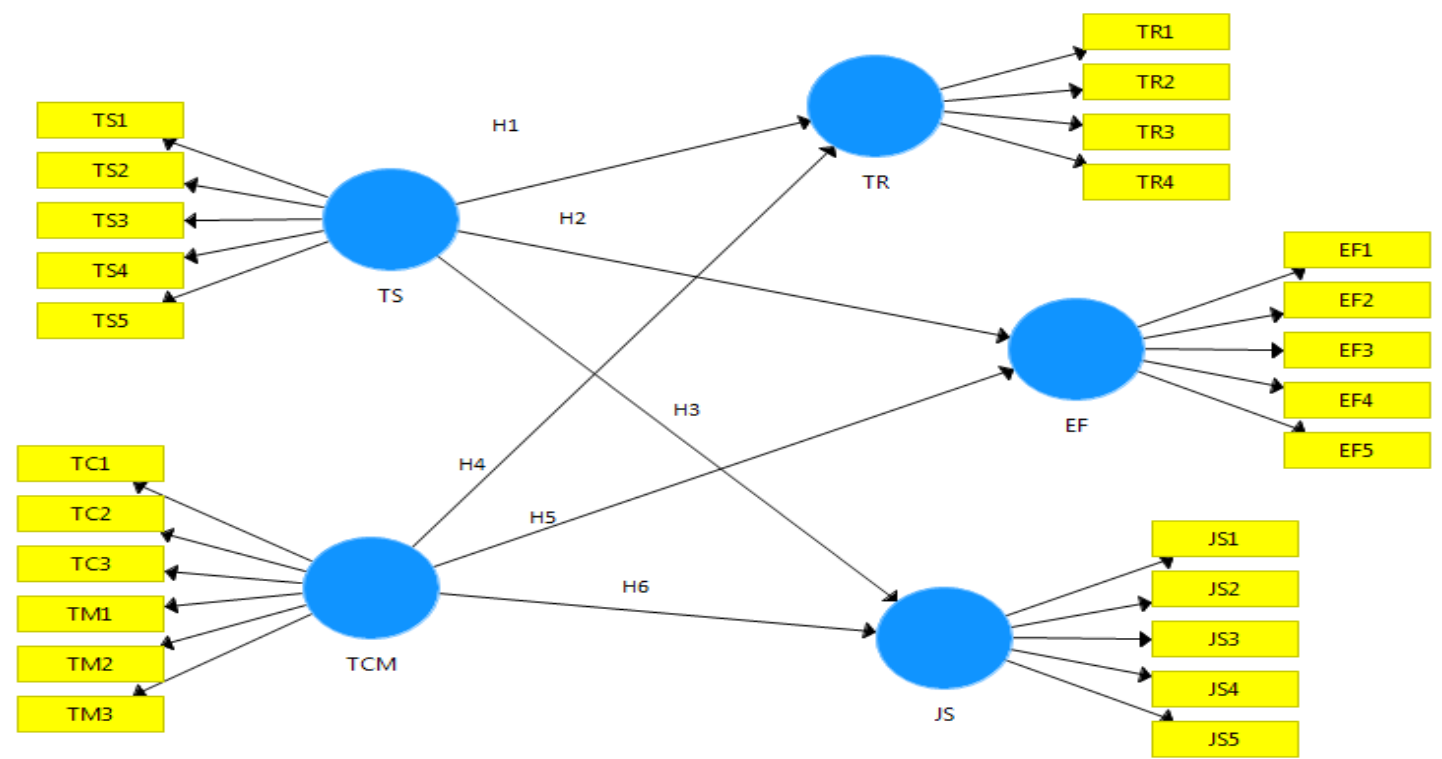

Source: Data Analysis of this study 


\section{DATA ANALYSIS AND RESULTS}

\section{Measurement Model}

Data analysis includes four parts analysis Reliability, coefficient paths, R-Square discriminant validity. In the meanwhile, a partial linear system (PLS-SEM) has been used for data analysis and findings.

\section{Factor Loadings, Composite Reliability, and Convergent Validity}

The composite reliability shows the internal consistency of the research as the more consistency exists, the more reliability will be drawn about the data. Conclusively, the higher results drew higher reliability (Jöreskog, 1971). However, as per the criteria, the composite reliability value lying between 0.6 and 0.7 is considered acceptable (Drolet \& Morrison, 2001). Furthermore, Cronbach's value is useful to gauge the internal consistency of the construct. Following Pallant and Tennant (2007), a value of 0.7 of Cronbach Alpha is agedness, but a value of more than 0.8 is suitable. Table 2 shows Cronbach Alpha's sole factors effect is beyond the lowest requirement and is thoroughly preferable.

While conducting research, considering average variance extracted is required to be must be defined as it measures the amount of variance that is used by building in connections to the figure of variance because of measurement variation (Classical test theory). Table 2 shows that the convergent validity and the requirement of average variance extracted are also met to accomplish the criteria of research. Further, the convergent validity testing also fulfilled all the requirements necessary to conduct the research that will require the outcome. It also shows the importance of loading, Cronbach alpha composite reliability, and discriminate validity. Meanwhile, the research conducted on average variance extracted is above 0.5 which is acceptable according to the defined threshold limit of acceptance. As discriminate validity is also lying under the domain of research acceptance because as we compare each constructed average variance extracted with the discriminate validity, we conferred that the average variance extracted is less than the discriminate validity. The researcher proposed the conventional metric and prescribed that each constructed average variance extracted needs to be compared with the square dinger-construct correlation of the same construct. Meanwhile, the shared variance for all models should not be larger than the concerned average variance extracted (Farnell, and Larker, 1981). The R2 measures the variances about the data and also refers to the predictive power and needs to be remaining in between 0 to 1 . As the chart of R2 shows that all the variances are considered moderate because the conclusive outcome falls 
between 0.5 to 0.75 . Comparatively the outcome less than 0.25 can be considered weak but in some contexts, a value lowers than 0.10 can also be acceptable under certain specific disciplines.

Table 2. Factor Loadings, Composite Reliability, and Convergent Validity

\begin{tabular}{|c|c|c|c|c|c|}
\hline Variables & Loading & $\begin{array}{c}\text { Cronbach's } \\
\text { Alpha }\end{array}$ & $\begin{array}{l}\text { Composite } \\
\text { Reliability }\end{array}$ & $\begin{array}{c}\text { Average } \\
\text { Variance } \\
\text { Extracted } \\
(\mathrm{AVE}) \\
\end{array}$ & No of Items \\
\hline \multicolumn{6}{|c|}{$\begin{array}{c}\text { Transformational } \\
\text { leadership }\end{array}$} \\
\hline TS1 & 0.749 & & & & \\
\hline TS2 & 0.713 & & & & \\
\hline TS3 & 0.83 & 0.783 & 0.852 & 0.539 & 5 \\
\hline TS4 & 0.764 & & & & \\
\hline TS5 & 0.594 & & & & \\
\hline \multicolumn{6}{|l|}{$\begin{array}{l}\text { Transactional } \\
\text { leadership }\end{array}$} \\
\hline $\mathrm{TC} 1$ & 0.731 & & & & \\
\hline TC2 & 0.694 & 0.814 & 0.866 & 0.523 & 6 \\
\hline $\mathrm{TC} 3$ & 0.805 & & & & \\
\hline TM1 & 0.842 & & & & \\
\hline TM2 & 0.592 & & & & \\
\hline TM3 & 0.644 & & & & \\
\hline \multicolumn{6}{|c|}{ Job Satisfaction } \\
\hline JS1 & 0.711 & & & & \\
\hline JS2 & 0.823 & 0.773 & 0.846 & 0.526 & 5 \\
\hline JS3 & 0.765 & & & & \\
\hline JS4 & 0.622 & & & & \\
\hline JS5 & 0.688 & & & & \\
\hline \multicolumn{6}{|l|}{ Extra efforts } \\
\hline EF1 & 0.702 & & & & \\
\hline EF2 & 0.671 & 0.791 & 0.857 & 0.546 & 5 \\
\hline EF3 & 0.748 & & & & \\
\hline EF4 & 0.785 & & & & \\
\hline EF5 & 0.78 & & & & \\
\hline \multicolumn{6}{|l|}{ Trust } \\
\hline TR1 & 0.695 & & & & \\
\hline TR2 & 0.758 & 0.740 & 0.836 & 0.561 & 4 \\
\hline TR3 & 0.741 & & & & \\
\hline TR4 & 0.8 & & & & \\
\hline
\end{tabular}

Table 3. Discriminant Validity

\begin{tabular}{lrrrrr}
\hline & EF & JS & TCM & TR & TS \\
\hline EF & 0.739 & & & & \\
JS & 0.605 & 0.725 & & & \\
TCM & 0.612 & 0.592 & 0.723 & & \\
TR & 0.646 & 0.622 & 0.682 & 0.749 & \\
TS & 0.556 & 0.579 & 0.53 & 0.589 & 0.734 \\
& & & & & \\
\hline
\end{tabular}

Source: Data Analysis of this Study 


\section{Hypothesis Testing}

Testing of hypotheses in this PLS involves the evaluation of the importance of direct and indirect effects, and the calculation of the impact of endogenous variables. The direct research with the Smart PLS 3.0 was performed using the t-statistic test in the partial less squared analysis (PLS). The structural model depicts in Model 2 gives values of casual relationship amongst the standardized variables in the form of standardized outcome values and t-value.

Figure 3. Structural Model

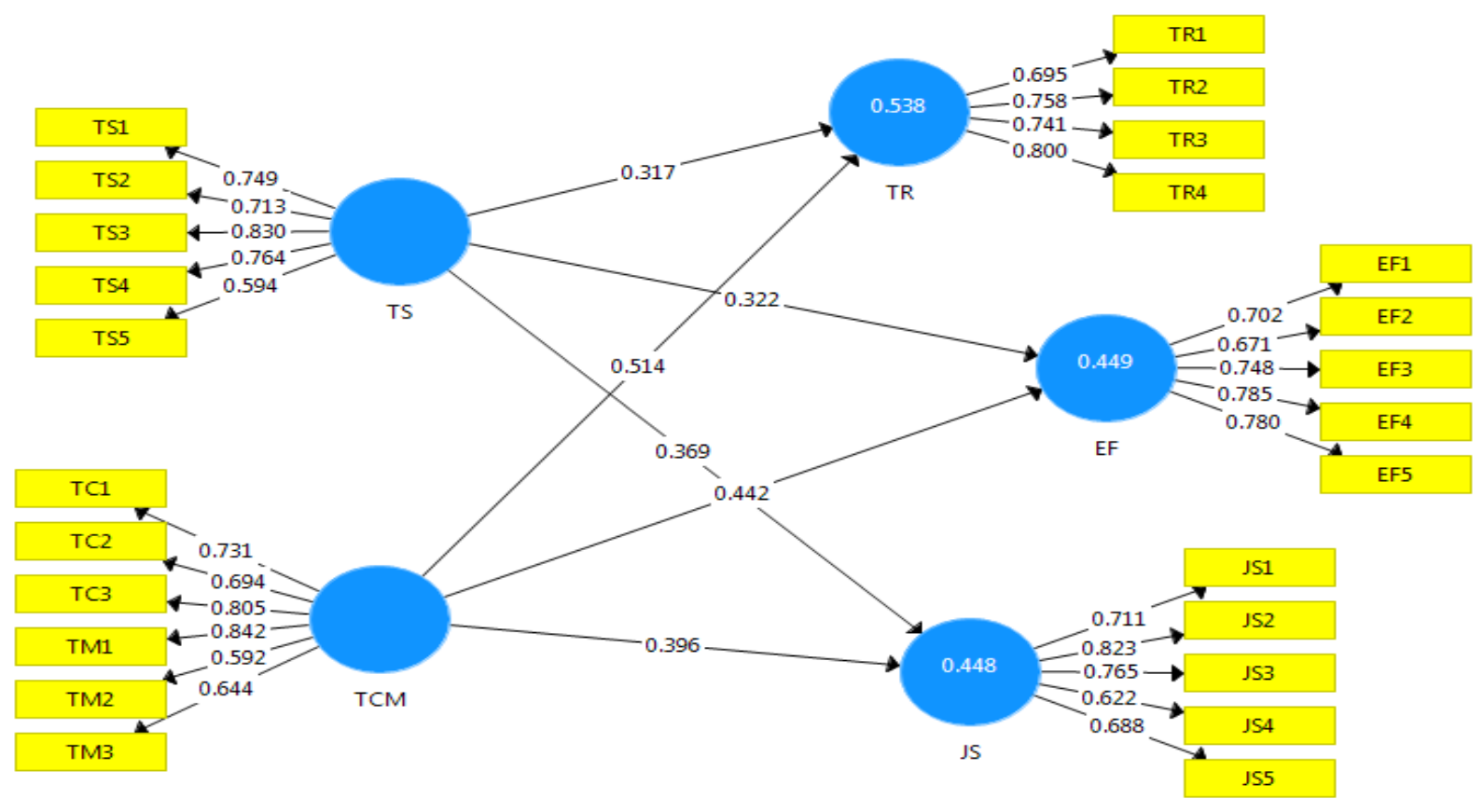

Source: Data Analysis of this study

\section{Structural Model}

The effect of Transformational leaderships on Employee Trust, Extra Efforts, Job Satisfaction.

The effect of Transformational leaderships on Employee Trust is positive (0.317) and significant $(5.908>1.96)$ and P-Value $(0.000<0.05)$. This finding is also speculated by Ben and Agu 2012 that in panic and tough situations the success of transformational leadership style depends on trust which fosters the healthy relationship and works culture. Further, research outcomes are also consistent with past studies of Walumbwa and Lawler (2003), who endorsed that transformational leadership styles are more effective in assessing significantly higher trust levels. Additionally, Diaz-Saenz (2011) also endorsed the finding of the quality of transformational leaders' judge based on behaviors towards their leaders by the trust. 
Furthermore, effect of Transformational leaderships on Extra Efforts is positive (0.322) and significant $(5.216>1.96)$ and P-Value $(0.000<0.05)$. This finding is also supported by Asrarul-Haq and Kuchinke (2016) that the transformational leadership style enhances the different levels of job satisfaction and influenced employees willingly for extra efforts to achieve the required objective. Further, (Doucet et al, 2015; Hater \& Bass, 1988) endorsed those transformational leaders always motivate their employees to assess a certain level of expectations by putting in the extra effort. However, effect of Transformational leaderships on Job Satisfaction is positive (0.369) and significant $(6.65>1.96)$ and P-Value $(0.000<0.05)$. This study also supports the findings of Hater and Bass, (1988) they claimed that the role of transformational leadership style is to influence the employees to achieve a level of job satisfaction. Further, it also endorsed that the transformational leadership role is helpful to reduce the strain level which increases job satisfaction and self-confidence. Further, job satisfaction is concerned with Transformational leadership style and transformational leader's decision-making behaviors. Purwanto et al., (2019) also claimed that Transformational leadership has a remarkable impact on job satisfaction.

\section{The Effect of Transactional leaderships on Employee Trust, Extra Efforts, Job Satisfaction}

The effect of Transactional leaderships on Employee Trust is positive (0.514) and significant $(8.478>1.96)$ and P-Value $(0.000<0.05)$. This finding also underwrites Burns $(1978)$ that transaction leadership is a way to build a strong and healthy connection between leaders and employees through commitment and trust. Moreover, the effect of Transactional leaderships on Employee Extra Efforts is positive (0.442) and significant $(6.773>1.96)$ and P-Value $(0.000$ $<0.05)$. This research is also endorsed by Burns, 1978 that transactional leaders assess both levels of employees and leaders and believe in extra efforts by employees. Besides, the transactional leadership style used a carrot and stick approach to reach the required goals (Bass, 1997). They also claimed that employees put more work and effort for increase organization productivity under the transactional leadership style. Additionally, the effect of Transactional leaderships on Employee Job Satisfaction is positive (0.396) and significant (5.964 > 1.96) and P-Value $(0.000<0.05)$. These outcomes are also in line with the research lead by Purwanto et al., (2019) that Transactional Leadership has a notable impact on the job satisfaction of employees. Further, Santoso (2019) have endorsed this finding that transactional Leadership has a remarkable impact on Job Satisfaction.

Table 4. Path Coefficients 
Significance $95 \%$

\begin{tabular}{cccccc}
\hline Hypothesis & Relationships & Original Sample(O) & STDEV & T-values & P-Values \\
\hline H1 & TS -> TR & 0.317 & 0.054 & 5.905 & 0.000 \\
H2 & TS -> EF & 0.322 & 0.062 & 5.216 & 0.000 \\
H3 & TS -> JS & 0.369 & 0.055 & 6.685 & 0.000 \\
H4 & TCM -> TR & 0.514 & 0.061 & 8.478 & 0.000 \\
H5 & TCM -> EF & 0.442 & 0.065 & 6.773 & 0.000 \\
H6 & TCM -> JS & 0.396 & 0.066 & 5.964 & 0.000 \\
\hline
\end{tabular}

Source: Data Analysis of this study

\section{DISCUSSION}

The entire research has played a significant role to evaluate the impact of transformational and transactional leadership styles during Covid-19. The leadership style is thoroughly associated with employees' outcomes because the ultimate core of leadership is originated with organizational success which is measured in terms of outputs. Hence, the efficiency of the outcome is associated with the employees' trust, extra efforts, and satisfaction. The actual purpose of the research is to collect the data from all three hierarchies of management as upper, middle, and lower to calculate the 360-degree impact of leadership upon the employees and their concerned performance during Covid 19. Telecom Sector is one of the most testing areas for leadership to improve the employees' performance.it is however noted that females have departed the Telecom Sector during Covid-19. Therefore, the obtained data has shown the male-occupied and dominant but the cause of less female participation remain vague. Conclusively, it is found that both styles of leadership as transactional and transformational played a significant role during Covid-19 to enhance and maintain the employee's performance concerning job satisfaction, maintained the trust and not even put the additional burden and gained further efforts to maintain the work efficiency.

Transformational leaders propose that transform short-term objectives and put peek-order intrinsic needs; meanwhile, transactional leaders put more focus to exchange the availability of resources (Erkutlu, 2008). It cannot vary from Burns's (1978) principle of transactional management that upwards it's sticking by demanding their adherents' interests (Yukl \& Mahsud, 2010). Undoubtedly, the crisis keeps the leadership tactics of a leader to a real test, no matter what the reason for the crisis is. Occasionally numbers or key performance indicators (KPI's), earning per share, turnover, and cost, all connected to revenue conclusion are used to evaluate a successful leader (McNulty \& Marcus, 2020). 


\section{LIMITATIONS OF THE STUDY}

There are certain limitations as well while conducting research such as the collection of data is simply restricted to the private sector specifically in Telecom Sector but not stretched to the rest of the industrial arena. Further, the certainty about the data collection regarding research is also a bit twisting because of the Covid-19. Furthermore, the sampling data is also limited (243 responses) on the basis of which study conclusions are drawn. Meanwhile; it is focused upon the two styles of leadership style as transformational and transactional leadership.

\section{CONCLUSION}

This research indicates what are the employees' assumptions and beliefs towards leadership style and this research is also useful to managers to make out which kind of leadership style is more worthwhile in the terms of employees' outcomes and which style they can adopt for effective future-oriented outcomes. Surprisingly, the competition in the telecom sector specifically in Pakistan has dramatically increased because of Covid-19. Many organizations have moved toward remote working systems as a result of the demand of the Telecom Sector are going to be increased day by day. It may be Pointed out that transactional behaviors', such as finding limitations and dividing feedback, will enhance employees' motivation (Zhu et al, 2018) and inspire the individuals learning. Further, the transactional leadership style perceived the bunch of co-worker's satisfactions that emerging from their day-to-day performances and then motivate the employees to attain those objectives by forcing them with rewards or sanctions (Bass \& Avolio, 1994). Moreover, making explicit and rectifying the affiliation between employees' Courses and eventually, rewards will also spike motivation (Vroom, 1964). Additionally, past researches by Walumbwa and Lawler (2003) put those leaders who demonstrate transformational leadership styles are highly inspiring in attaining notably up mark commitment stages in terms of trust and job satisfaction. The conclusion on employee motivation also windup that awarding and inspiring these are the salient characters in Transformational leadership styles and is perpetually to be one of the significant motivators (Erkutlu, 2008).

\section{Acknowledgments:}

The authors acknowledged that the manuscript is original and has not been submitted anywhere. There is no financial or non-financial support in this study.

\section{Author(s) Contributions:}

All co-authors have equally contributed to this article. 


\section{REFERENCES}

Alves, J. C., Lok, T. C., Luo, Y., \& Hao, W. (2020). Crisis management for small business during the Covid-19 outbreak: Survival, resilience and renewal strategies of firms in Macau. Doi: 10.21203/rs.3.rs-34541/v1.

Asrar-ul-Haq, M., \& Kuchinke, K. P. (2016). Impact of leadership styles on employees' attitude towards their leader and performance: Empirical evidence from Pakistani banks. Future Business Journal, 2(1), 54-64. https://doi.org/10.1016/j.fbj.2016.05.002

Bass, B. M. (1985). Leadership: Good, better, best. Organizational dynamics, 13(3), 26- 40. https://doi.org/10.1016/0090-2616(85)90028-2

Bass, B. M. (1997). Does the transactional-transformational leadership paradigm transcend organizational and national boundaries? American psychologist, 52(2), 130.

Bass, B. M., Avolio, B. J., Jung, D. I., \& Berson, Y. (2003). Predicting unit performance by assessing transformational and transactional leadership. Journal of applied psychology, 88(2), 207. https://doi.org/10.1037/0021-9010.88.2.207 (apa.org)

Bass, B. M., \& Avolio, B. J. (1994). Transformational leadership and organizational culture. The International Journal of Public Administration, 17(3-4), 541-554. https://doi.org/10.1080/01900699408524907

Bello, S. M. (2012). Impact of ethical leadership on employee job performance. International Journal of Business and Social Science, 3(11).

Ben, E. U., \& Agu, O. A. (2012). Impact of transformational and transactional leadership on organizational performance. International Journal of Current Research, 4(11), 142-147.

Berkovich, I., \& Eyal, O. (2018). The effects of principals' communication practices on teachers' emotional distress. Educational management administration \& leadership, 46(4), 642-658. https://doi.org/10.1177\%2F1741143217694894

Broberg, E. K., Waris, M., Johansen, K., Snacken, R., \& Penttinen, P. (2018). Seasonality and geographical spread of respiratory syncytial virus epidemics in 15 European countries, 2010 to 2016. Eurosurveillance, 23(5), 17-00284. https://doi.org/10.4324/9780203077108

Bronkhorst, B., Tummers, L., Steijn, B., \& Vijverberg, D. (2015). Organizational climate and employee mental health outcomes: A systematic review of studies in health care 
organizations. Health care management review, 40(3), 254-271. 10.1097/HMR.0000000000000026 (doi.org)

Bundy J, Pfarrer MD, Short CE, Coombs WT. Crises and crisis management: Integration, interpretation, and research development. Journal of management. 2017 Jul;43(6):166192. https://doi.org/10.1177/0149206316680030

Burns, J. M. G. (1978). Leadership. New York: Harper \& Row.

Chen, J., \& Silverthorne, C. (2005). Leadership effectiveness, leadership style and employee readiness. Leadership \& Organization Development Journal, 26, 280-288. https://doi.org/10.1108/01437730510600652

Davis, G., \& Rhodes, R. A. (2020). From hierarchy to contracts and back again: reforming the Australian public service. In Institutions on the Edge? (pp. 74-98). Routledge. 10.4324/9781003116127-4 (doi.org)

Diaz-Saenz, H. R. (2011). Transformational leadership. The SAGE handbook of leadership, 5(1), 299-310.

Doucet, O., Fredette, M., Simard, G., \& Tremblay, M. (2015). Leader profiles and their effectiveness on employees' outcomes. Human Performance, 28(3), 244-264. https://doi.org/10.1080/08959285.2015.1021039

Drolet, A. L., \& Morrison, D. G. (2001). Do we really need multiple-item measures in service research? Journal of service research,3(3), 196-204. Doi: https://doi.org/10.1177/109467050133001

Erkutlu, H. (2008). The impact of transformational leadership on organizational and leadership effectiveness. Journal of management development.

Fitch, P., \& Van Brunt, B. (2016). A guide to leadership and management in higher education: Managing across the generations. Routledge. https://doi.org/10.4324/9781315691596

Gibb A., Haskins G., Robertson I. (2013) Leading the Entrepreneurial University: Meeting the Entrepreneurial Development Needs of Higher Education Institutions. In: Altmann A., Ebersberger B. (eds) Universities in Change. Innovation, Technology, and Knowledge Management. Springer, New York, NY. https://doi.org/10.1007/978-146144590-6_2 
Goleman, D. (2010). Why leading sustainability matters more than ever. People \& Strategy, 33(1), 7-9.

Gotsis, G. and Grimani, K. (2016), "Diversity as an aspect of effective leadership: integrating and moving forward", Leadership \& Organization Development Journal, 37(2), 241-264. https://doi.org/10.1108/LODJ-06-2014-0107

Hasan, A., \& Rjoub, H. (2017). The role of effective leadership styles in crisis management: a study of Erbil, Iraq. International Journal of Economics, Commerce and Management, 5(4), 107-121.

Hater, J. J., \& Bass, B. M. (1988). Superiors' evaluations and subordinates' perceptions of transformational and transactional leadership. Journal of Applied psychology, 73(4), 695. https://psycnet.apa.org/record/1989-13808-001

Hodges, J., \& Howieson, B. (2017). The challenges of leadership in the third sector. European Management Journal, 35, 69-77. 10.1016/J.EMJ.2016.12.006

Hon, L. C., \& Grunig, J. E. (1999). Guidelines for measuring relationships in public relations.

Jamnik, V., Gumienak, R., \& Gledhill, N. (2013). Developing legally defensible physiological employment standards for prominent physically demanding public safety occupations: a Canadian perspective. European journal of applied physiology, 113(10), 2447-2457. https://doi.org/10.1007/s00421-013-2603-1

Jöreskog, K. G. (1971). Statistical analysis of sets of congeneric tests. Psychometrika, 36(2), 109-133. https://doi.org/10.1007/BF02291393

Karp, T., \& Johannessen, J. A. (2010). Earning the right to lead in defining moments: The act of taking leadership. The Journal of Values-Based Leadership, 3(1), 4.

Li, C., \& Shi, K. (2008). The structure and measurement of transformational leadership in China. Frontiers of Business Research in China, 2, 571-590.

Madanchian, M., Hussein, N., Noordin, F., \& Taherdoost, H. (2017). Leadership effectiveness measurement and its effect on organization outcomes. Procedia Engineering, 181, 10431048. https://doi.org/10.1016/j.proeng.2017.02.505

McCarthy, A., Darcy, C., \& Grady, G. (2010). Work-life balance policy and practice: Understanding line manager attitudes and behaviors. Human Resource Management Review, 20(2), 158-167. https://doi.org/10.1016/j.hrmr.2009.12.001 
McNulty, E. J., \& Marcus, L. (2020). Are you leading through the crisis... or managing the response? Harv Bus Rev [serial online]. March.

Mullins, V., \& Debra, K. (2007). The Relationship between Leadership Styles and Organizational Culture within Schools of Nursing.

Niqab, M., Singh, S., \& Shaikh, S. (2019). Fuzzy Based Principal's Leadership Skills Assessment Model for Secondary Schools. Journal of Independent Studies \& Research: Management \& Social Sciences \& Economics, 17(2).

Nyenswah, T., Engineer, C. Y., \& Peters, D. H. (2016). Leadership in Times of Crisis: The Example of Ebola Virus Disease in Liberia. Health systems and reform, 2(3), 194-207. https://doi.org/10.1080/23288604.2016.1222793

Pallant, J. F., \& Tennant, A. (2007). An introduction to the Rasch measurement model: an example using the Hospital Anxiety and Depression Scale (HADS). British Journal of Clinical Psychology, 46(1), 1-18. https://doi.org/10.1348/014466506X96931

Park, J., Lee, K., Lim, J. I., \& Sohn, Y. W. (2018). Leading with callings: effects of leader's calling on followers' team commitment, voice behavior, and job performance. Frontiers in psychology, 9, 1706. https://doi.org/10.3389/fpsyg.2018.01706

Pitelis, C. N., \& Wagner, J. D. (2019). Strategic shared leadership and organizational dynamic capabilities. The Leadership

Quarterly, 30(2),

233-242. https://doi.org/10.1016/j.leaqua.2018.08.002

Ponnu, C.H., \& Tennakoon, G. (2009). The Association between Ethical Leadership and Employee Outcomes - the Malaysian Case. EJBO : Electronic Journal of Business Ethics and Organization Studies, 14, 21-32. http://urn.fi/URN:NBN:fi:jyu201010052947

Purwanto, A., Asbari, M., \& Budi Santoso, P. (2019). Influence of Transformational and Transactional Leadership Style toward Food Safety Management System ISO 22000: 2018 Performance of Food Industry in Pati Central Java. Inovbiz: Jurnal Inovasi Bisnis, 7(2), 180-185. https://doi.org/10.35314/inovbiz.v7i2.1213

Rohmann, A. and Rowold, J. (2009), "Gender and leadership style: A field study in different organizational contexts in Germany", Equal Opportunities International, $\quad$ Vol. 28 No. 7, pp. 545-560. https://doi.org/10.1108/02610150910996399 
Rohrich, R. J., Hamilton, K. L., Avashia, Y., \& Savetsky, I. (2020). The Covid-19 pandemic: changing lives and lessons learned. Plastic and Reconstructive Surgery Global Open, 8(4). https://dx.doi.org/10.1097\%2FGOX.0000000000002854

Soydan, H., \& Palinkas, L. A. (2014). Evidence-based practice in social work: Development of a new professional culture. Routledge. https://doi.org/10.4324/9780203077108

Spinelli R. J. (2006). The applicability of Bass's model of transformational, transactional, and laissez-faire leadership in the hospital administrative environment. Hospital topics, 84(2), 11-18. https://doi.org/10.3200/HTPS.84.2.11-19

Squires, V. (2018). Northouse, PG (2016). Leadership: Theory and practice. Thousand Oaks, CA: Sage. Pages: 494. Canadian Journal of Educational Administration and Policy, (185).

Steinmann, B., Klug, H. J., \& Maier, G. W. (2018). The path is the goal: How transformational leaders enhance followers' job attitudes and proactive behavior. Frontiers in Psychology, 9, 2338. https://doi.org/10.3389/fpsyg.2018.02338

Turner, J. R., \& Müller, R. (2005). The Project Manager's Leadership Style as a Success Factor on Projects: A Literature Review. Project Management Journal, 36(2), 49- 61. https://doi.org/10.1177/875697280503600206

Vroom, V. H. (1964). Work and motivation.

Walumbwa, F. O., Orwa, B., Wang, P., \& Lawler, J. J. (2005). Transformational leadership, organizational commitment, and job satisfaction: A comparative study of Kenyan and US financial firms. Human resource development quarterly, 16(2), 235-256. https://doi.org/10.1002/hrdq.1135

Walumbwa, F. O., \& Lawler, J. J. (2003). Building effective organizations: Transformational leadership, collectivist orientation, work-related attitudes and withdrawal behaviours in three emerging economies. The International Journal of Human Resource Management, 14(7), 1083-1101. https://doi.org/10.1080/0958519032000114219

Williams, T. A., Gruber, D. A., Sutcliffe, K. M., Shepherd, D. A., \& Zhao, E. Y. (2017). Organizational response to adversity: Fusing crisis management and resilience research streams. Academy of $\quad$ Management $\quad$ Annals, 11(2), 733-769. https://doi.org/10.5465/annals.2015.0134 
White, L., Currie, G., \& Lockett, A. (2016). Pluralized leadership in complex organizations: Exploring the cross-network effects between formal and informal leadership relations. The Leadership Quarterly, 27(2), 280-297.

Yukl, G., \& Mahsud, R. (2010). Why flexible and adaptive leadership is essential. Consulting Psychology Journal: practice and research,62(2), 81. Doi: https://psycnet.apa.org/doi/10.1037/a0018957

Zander, A. (2018). Motives and goals in groups. Routledge. Doi: https://doi.org/10.4324/9781351308960

Zhu, Y. Q., Gardner, D. G., \& Chen, H. G. (2018). Relationships between work team climate, individual motivation, and creativity. Journal of Management, 44(5), 2094-2115. Doi: https://doi.org/10.1177/0149206316638161 